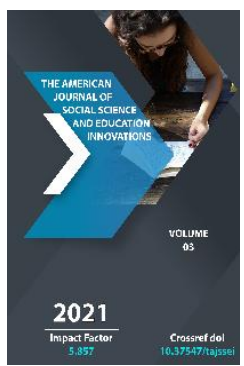

\title{
The Need For Social Protection In The Republic Of Uzbekistan And Its Legal Basis
}

Bekjon Salihovich Ismoilov

Tashkent State Law University, Researcher, Tashkent, Uzbekistan

Journal Website:

http://usajournalshub.c om/index,php/tajssei

Copyright: Original content from this work may be used under the terms of the creative commons attributes 4.0 licence.

\section{ABSTRACT}

The article analyzes in detail the role of social protection in the life of the population. The mechanism of functioning of the regulatory framework created in our country in this area has also been studied in detail. The content of scientific approaches to the concept of social protection is legally analyzed.

\section{KEYWORDS}

Social protection, social politics, republic, Action strategy, creativity, necessity, legal framework.

\section{INTRODUCTION}

At the next stage of the country's development, reforms aimed at improving the living standards of the population, ensuring their well-being, and providing economic support to people in need of social assistance have been significantly strengthened. As a result, government programs and legislation have been adopted. At the initiative of the 
President of the Republic of Uzbekistan Sh.M.Mirziyoev, the state programs "Strategy of Actions" for 2017-2021 were approved for the comprehensive development of the republic and a decent life of our people, the realization of the creative potential of our citizens. The decrees and resolutions of the President, introduced to radically update the state policy on economic development and poverty reduction, are also of particular importance in this regard.

\section{METHODS}

The article provides a scientific analysis of the generally accepted methods of analysis, ie the vital importance of social protection in the Republic of Uzbekistan and its legal basis on the basis of data studied on an analytical basis.

\section{RESEARCH RESULTS}

We know that the transition to a healthy competitive market economy is a complex process. The complexity of this process is that the constant changes in economic relations, the diversification of prices for consumer goods that meet the basic needs of people, have a direct impact on the financial situation of people with disabilities, the elderly and lowincome families. We believe that this situation can be taken objectively in countries that are developing their national economies. In such an environment, social protection of the vulnerable, creating decent living conditions for them has become one of the main goals of public policy. We believe that such care of our government should be considered as a high example of humanity. This is due to the fact that as a practical result of the reforms being carried out in our country, certain categories of individuals, low-income families are maintaining their economic balance. Therefore, it is no exaggeration to say that one of the most important aspects of social protection policy is the creation of decent living conditions for needy families. The views of the lawyer D.Ahmedov serve to reveal the essence of the concept: "Previously, social protection consisted only of assistance to the poor, today this concept includes increasing the level of employment of citizens, payment of wages in accordance with the quantity and quality of labor, social security, the implementation of the right to rest, high quality medical care, all aspects of ensuring a decent standard of living"'[2].

A.A.Razumov focuses on the other side of the issue: "If the focus is on social assistance and support in one form or another through various strata, and the number of recipients increases, then the state will inevitably become a social security department. It is clear that this will lead to a desire to work, an increase in poverty, and an increase in the mood of dependence"[3].

If we look at the essence of the matter, we can see that both of the above points are now at the actual level. For example, the first review explains that employment and decent wages are effective ways of social protection. It is possible to fully agree with this idea and support it. Because when people are employed, they are able to fully meet their socio-economic needs. This will significantly reduce the need of citizens for social protection and help ensure that social benefits reach families in need. In the second view, the fact that social assistance is not implemented on the basis of specific programs leads to excessive problems in the system. What we mean is that the lack of targeted organization of social assistance can lead to the disappearance of the business environment in society. According to the analysis of S. Smirnov 
and N. Isayev, "social policy consists of the sphere of domestic policy pursued by a particular state as the satisfaction of social needs of the population" [4]. According to BM Lazarev, "the concept of human social protection reflects the multifaceted relationship between man and society, and the discovery of the essence of this relationship opens up the possibilities of the individual" [5].

Today, a clear target system has been formed in the social protection policy of our country. This is a positive aspect, of course. The target system formed in this regard has such a complex nature that the activities of the sector are evaluated not only from a legal point of view, but also from the socio-economic point of view. Therefore, in the scientific literature, the concept of social assistance, which is the most important component of social protection, is considered as a phenomenon based on social, economic, philosophical and legal foundations. From a legal point of view, legal scholars have different views on the concept of social assistance. Some groups of scholars interpret this notion as a one-time measure aimed at non-routine assistance or natural services to citizens in need of social assistance. In some countries, social assistance is provided by the state, as well as by nongovernmental organizations on the basis of material resources. Speaking about this, the lawyer M.Usmanova said: "Social assistance is financial, financial assistance from the state to individuals and families in need of age, health, condition and other objective assistance, who are unable to solve their problems independently. and other forms. "In this regard, we also support the views of $M$. Usmonova, without denying the views of other authors. In our opinion, it is appropriate to provide social assistance to people who are unable to solve their problems on their own due to physical or mental disabilities. The implementation of such measures based on specific sectoral principles and specific programs will ensure the transparency of the sector. We think that these views of GV Suleymanova on the principles of the field bring originality to the analysis. According to him, "the principles of social protection include the universality and availability of such protection, the comprehensiveness and diversity of protection, the dependence of the amount of social protection on economic achievements, the implementation of special funds" [6].

Legal guarantee of stable operation of the mechanism of comprehensive support for people with disabilities, the elderly, orphans and families with many children;

- Development of appropriate methods of employment and proper organization of working conditions in the event of a pandemic;

- Further development of the system in the field of health, education and culture;

- Government provision of health facilities with medicines, vaccines and other medical supplies, prevention of morbidity, mortality and infant mortality;

- To prevent the reduction of state funding for the social sphere, to create a market mechanism for its extra-budgetary funding;

- It is noteworthy that a number of areas in the education and health care systems are being reformed within the framework of government programs, such as accelerating market changes and implementing measures to increase the financial interest of employees in the 
results of their work. The fact that the "Strategy of Action", founded by the head of our state, pays special attention to these issues, shows that the fate of the people, the future of our head of state and our government is in the spotlight. These strategic actions, which reflect the interests of the people and the future of the country, are a guarantee of development of the social sphere. While talking about the importance of social protection policy in the country, the program pays special attention to the components of the sector. In particular, education, health care, pensions and so on. It is obvious that social protection is the most important component of public policy. Because, as stated in Article 2 of the Constitution of the Republic of Uzbekistan, "The state, expressing the will of the people, serves its interests. The people are the only source of the state. " Therefore, it can be concluded that the social policy pursued in our country is a vital necessity of social life. Honorable President Sh.M. Mirziyoyev's address to the Oliy Majlis in late 2020 also focused on further improving the social sphere and introducing a new system of care for the needy. In particular, a very important initiative was put forward to introduce a new system based on special care measures for children from needy families, orphans, children with disabilities and those in need of treatment. We also fully support these initiatives of our President. After all, we believe that the future of a state that considers the realization, expression and protection of the interests of the people as its highest goal will be bright and strong.
Social protection is a state policy aimed at ensuring the full life and work of citizens in need of assistance due to age, health, social status, inadequate means of subsistence. Public administration is based on the principle of social justice. As stated in Article 14 of our encyclopedia, "The state shall carry out its activities on the basis of the principles of social justice and the rule of law, for the benefit of man and society." Therefore, one of the necessary conditions of social protection policy is to act only on the basis of fairness in providing financial support to the population. When we talk about social policy, it is appropriate to pay special attention to the concepts of social protection and social security, which are considered to be the most important criteria of governance. This is because, although the practical application of this concept has a certain history, the opinions expressed about it are peculiarly ambiguous.

The growing need for social protection in the context of market relations is also leading to the formation of different scientific and theoretical views on the concept. According to V. Kudryavtsev, social protection means that a person is protected by strong social and legal guarantees [7, P.30-38].

According to V. Galaganov, social protection is a social assistance of the state, one of the organizational and legal forms of social security [8, P.39]. TK Mirona comments: "It is not expedient to include social protection in the subject of social security law" [9, P.34]. Lawyer D. Ahmedov defines the concept of social protection as follows: "Social protection is a set of activities of the state to create favorable conditions for the individual life of the individual and the family in the implementation of social rights of the individual [2, P.31 ]". Speaking about the policy 
of social protection, Y. Tursunov puts forward the following views: "The policy of social protection of the population is based on constitutional principles, from dependence and social security of the state to the real vulnerable groups (pensioners, the disabled), orphans, large families, etc.) should be further developed based on the transition to targeted support [10, P.6]".

I.S.Maslov considers the concept of social protection as an important element of direct social protection policy and thinks: "The core of active social policy is employment policy, income policy. As the most important component of social policy, employment policy should be considered to encourage the creation of conditions for the full employment of able-bodied people in labor and business activity, and this is one of the most effective measures against mass poverty and unemployment "[11, P.4].

In our opinion, social protection is a set of socio-economic and legal measures taken by the state on a regular basis to support the most vulnerable segments of the population. The social protection system of our country, which has a guaranteed legal basis, directly supports the poorest and most vulnerable segments of the population. The reason is that this process is one of the main goals of our state policy. Because social protection policy is directly linked to the lives of the people, reforms in this area will be carried out in the context of social assistance, various benefits and socio-legal guarantees. At the same time, the support of the population at the state level is an integral part of social policy. In this regard, the cooperation of central and local governments is important for the effective development of the industry. We know that low incomes are more common in local areas, such as districts, cities, and villages. If we take an objective approach to the situation, it should be noted that it is difficult to find self-employment in foreign regions or to get a job for a normal salary. It is at these points that the activity and initiative of local authorities are required. An indepth study and analysis of the situation of the local population by the responsible authorities will help to take an open look at the existing problems. The organization of governance in the social sphere in accordance with the principles of humanity and justice is an important factor in the proper functioning of society. Social protection in the country is based on the implementation of measures to address specific problems in the field of health, education, employment and other areas, as well as the proliferation of similar problems. These reforms, of course, will greatly contribute to a positive change in the lives of the population. N.B. According to Azarov, in order to effectively manage society, the state must perform two important tasks: 1) define social goals and objectives, fully attract material and other resources to properly perform the assigned task; 2) prepare a concept of legislation to the extent that it can ensure the implementation of social policy [12, P.6-17]. According to MA Usmonova, it is a constitutional obligation of the state to protect citizens from the difficulties of the transition to market relations, to establish economic and legal mechanisms of social protection and to ensure their proper functioning [13].

If we take a closer look at the content of the above points, we will see that these considerations imply that the state must act systematically to prioritize its social policy and strengthen this system with an excellent legal framework. Indeed, we believe that the functioning of laws as a whole mechanism in 
any field and the establishment of systematic activities in the field are a reliable guarantee of positive results. In this sense, it can be concluded that social policy is a process that takes into account the needs of the people, requires constant updating and continuity. If we study the systemic measures taken by our country in the field of social policy since independence, it is true that this process is based on the principles of social justice and humanity. We are convinced that it is a system of targeted reforms. Therefore, since the first years of independence, a number of measures have been taken to improve the living standards of people with disabilities, pensioners and large families. In this regard, on November 18, 1991, the Law "On Social Protection of Persons with Disabilities in Uzbekistan" was adopted. The law provides for the exercise of the rights and freedoms of persons with disabilities, the removal of various restrictions and barriers to their integration into society, the legal guarantee of their equal rights with citizens, and their active participation in the political and economic life of society. caught. True, the law was revised in 2008 and put into practice. In addition, the Law on the Rights of Persons with Disabilities, approved by the Senate of the Oliy Majlis on September 11, 2020, is also a priority in this regard. That is to say, the legal framework for social protection dates back to the early years of independence. On August 24, 1994, the Decree of the First President of the Republic of Uzbekistan "On measures to strengthen the social protection of low-income families" was adopted. According to the decree, the state introduced the concept of financial assistance to improve the situation of low-income families. In 1995 alone, more than 500,000 lowincome families received a total of 6 billion soums in financial assistance from local organizations. Also on December 10, 1996, a presidential decree was issued to provide financial support to large families. The decree "On further strengthening of state support for large families" introduced monthly benefits for low-income families with children under 14 years of age. Families' need for pensions will be studied by local self-government bodies, and financial assistance will be provided on the basis of special findings. Effective January 1 , 1997, low-income families will receive between 50 percent and 175 percent of the minimum wage. It is based on the number of children from low-income families. In these cases, strict adherence to the principles of social justice has been established.

On December 7, 1999, the Cabinet of Ministers of the Republic of Uzbekistan adopted a resolution "On the program of measures to strengthen the social protection of lonely pensioners and the disabled for 2000-2005." The resolution considers it appropriate to attract funds from foreign sponsors and investors in order to further strengthen the material and technical base of boarding schools for children with disabilities, their communities, and nursing homes. The decision, implemented by the Cabinet of Ministers, has made a significant contribution to strengthening the social protection of lonely elderly people and improving their living conditions.

In the context of Uzbekistan, the measures taken on a regular basis to further support the population in need of social assistance have become very important in recent years. Because these reforms began to appear not in the form of specific measures, but as state programs of the year. In particular, the personal support of people with disabilities by the head of our state was noted as a bright 
manifestation of social protection policy. In particular, the Decree of the President of the Republic of Uzbekistan dated August 1, 2017 No. F-5006 "On measures to radically improve the system of state support of persons with disabilities" provides a solid legal basis in this regard. accepted as. The decree is seen as an effective force in the early detection and prevention of disability, the provision of medical and social assistance to persons with disabilities, vocational training and employment. In addition, in the next stages of development of our country, significant changes have been observed in all spheres of social spheres. In particular, the subjectivity of the approach to the poverty and poverty of some families in the social administration of the country shows that there are radical positive changes in the social policy of our country. In particular, on February 27, 2020, in a video conference dedicated to the "Establishment of a system of measures to reduce poverty through the development of entrepreneurship," the head of state criticized the weakening of social policy. In this video conference, the causes of poverty and its social boundaries were discussed, and relevant recommendations and suggestions were made to develop ways and means to overcome the existing problems in this area. Decree of the President of the Republic of Uzbekistan No. PF5975 of March 26, 2020 "On measures to radically update the state policy on economic development and poverty reduction" is the main step in all reforms in the field of poverty reduction. factor. It should be noted that there are certain approaches to the concept of poverty in the scientific literature or official documents. For example, "low-income families", "low-income families" and so on. In this regard, the government has introduced a number of regulations on financial support for large and low-income families. However, their implementation in society was not at its level. That is, the scope of the legal norms was relatively different. There are certain shortcomings in the targeted and targeted delivery of financial assistance provided by the state to the needy. In recent years, wellthought-out and positive work has begun to develop a mechanism to prevent such shortcomings and to prevent the occurrence of such problems. As a result, the effective system of social protection has been radically renewed. In particular, the reduction of poverty among the population and the radical improvement of their living standards have become the main activities of the modernized system. The fact that the President pays close attention to the main aspects of the problem and takes practical measures to address it, testifies to the effective and consistent reform of the industry.

\section{CONCLUSIONS}

Based on the above considerations, we present the following concluding remarks and recommendations that may help to record the effective results of the practical work carried out in the framework of social policy in our country.

1. Development of the draft law "On social policy" and its submission for public discussion. Over time, the foundations of the social sphere and their components are being renewed, changed and diversified. While this diversity is recognized as beneficial in some ways, on the other hand it poses some challenges for people who do not have sufficient legal knowledge. In our opinion, it is useful to have a clear fundamental representation of the legal 
framework in governance in the social sphere.

2. Adoption of a social code that summarizes the legal framework of the social sphere. In this regard, we consider it appropriate to study the experience of the German national legal system.

\section{REFERENCES}

1. The Constitution of the Republic of Uzbekistan. - Toshkent, 2016. Articles 2-714.

2. Ahmedov D. Legal basis of state social protection // Handbook. - Tashkent, 2008. - P.31.

3. Razumov A.A. States and social protection: problems of poverty and unemployment. - Moscow: 1997. - P. 4.

4. Smirnov S., Isaev N. Social policy: a new course. // Economic Issues. 1999, no. 2. C.68

5. Lazarev B.M. Public service. - Moscow: Institute of State and Law ANYU, 1993. P.32

6. Sulaimonova G.V. // Social Security Law. Moscow: Yurayt, 2017.430 b.

7. Kudryavtsev V., Lukasheva E. New political thinking and human rights // Man and politics, 1991. - pp. 30-38.

8. Galaganov V. Russian social security: problems and development prospects // State and law, 1992. No. 12. - P. 39.

9. Mironova T.K. Development of Social Security Legislation: State and Law, 1995. P. 34 .

10. Tursunov Y. Social Security Law (Textbook for Vocational Colleges). - T.: Teacher, 2005. P-6.

11. Maslov I.S. Key issues of regulation of the social and labor sphere. Analytical bulletin. - Moscow: 1997 .- P. 4.
12. Azarov N.B. On the problems of implementation of the main directions of social policy. M., 1997 .-- S. 6-17.

13. Usmonova M.A. Business entities and social protection. Problems of small and private business development in Uzbekistan. Proceedings of the scientificpractical conference. - T .: TDYul, 2002.133p.

14. Decree of the President of the Republic of Uzbekistan "On further strengthening the state support of large families." December 10, 1996.

15. Resolution of the Cabinet of Ministers of the Republic of Uzbekistan "On the program of measures to strengthen the social protection of lonely pensioners and the disabled for 2000-2005." December 7, 1999. 